\title{
UPAYA MENCIPTAKAN BIROKRASI YANG IDEAL DAN PENINGKATAN KUALITAS APARATUR PEMERINTAH
}

\author{
Oleh: Rosidah
}

Abstrak

rosidah@uny.ac.id

Pembangunan bangsa memerlukan tatanan birokrasi yang ideal serta tersedianya sumber daya manusia (SDM) yang profesional. Dalam pencapaiannya pertu reevaluasi temadap keberadaan birokrasi dan SDM yang ada. Beberapa hambatan dalam menuju sasaran-sasaran pembangunan, tidak lepas dari faktor elitis, politik dan patologi birokrasi yang bersumber dari manusia. Oleh karena itu pertu modernisasi birokrasi dan peningkatan mutu, melalui Total Quality Management didalam proses penyelenggaraan pemerintahan.

\section{Latar Belakang Masalah}

Era deregulasi ini, birokrasi masih menjadi istilah pejoratif. Kata 'birokratis' atau cara-cara yang lazim berlaku dalam birokrasi, diasosiasikan dengan tidak efisien, prosedur yang berbelit-belit, kemacetan/keterlambatan, pelayanan kurang memuaskan. Data dari riset, yang dibuat oleh lembaga rating Political and Economic Research Consultancy (PERC) kepada kalangan bisnis di 13 negara Asia, Indonesia menempati no. 9 yang termasuk negara yang efektivitas birokrasinya rendah. Dilaporkan pula bahwa mayoritas warga $(74 \%)$ menganggap para aparat pemda dalam menjalankan tugasnya cenderung berperilaku bukan sebagai abdi masyarkat melainkan lebih condong sebagai abdi negara, $55 \%$ warga menganggap aparat mempersulit urusan mereka, $59 \%$ warga menganggap pekerjaan aparat tidak efisien dan efektif.

Seiring dengan kemajuan masyarakat, birokrasi dituntut untuk lebih peka terhadap perubahanperubahan masyarakat. Birokrasi tidak saja dituntut untuk lebih efisisen dan produktif, melainkan juga turut berperan dalam pemberdayaan masyarakat dalam pembangunan.

Dalam peranannya sebagai pemberdaya, perlu pembenahan di bidang administrasi dan birokrasi, yang dikenal dengan reformasi administrasi diartikan sebagai penggunaan wewenang untuk menerapkan peraturan baru terhadap sistem administrasi untuk mengubah tujuan, struktur maupun prosedur, yang dimaksudkan untuk mempermudah 
pencapaian tujuan pembangunan. Arah dari pembangunan adminstrasi dan aparatur di Indoriesia dinyatakan dalam GBHN 1998 bahwa strategi pembangunan bagi aparatur pemerintah diarahkan pada peningkatan kualitas dari keseluruhan sistem administrasi negara termasuk di dalamnya adalah pembangunan SDM yang memiliki disiplin, tanggung jawab, kejujuran, kemampuan profesional, wawasan pembangunan dan semangat pengabdian kepada masyarakat, bangsa dan tanah air. Sejalan dengan itu perlu diupayakan kewenangan yang rasional diantara jajaran dan peringkat aparatur negara sehingga terlaksana penyelenggaraan administrasi negara yang bersih, profesioanl, efisien dan efektif.

Menurut teori Max Weber, birokrasi pada hakekatnya mengandung makna pengorganisasian yang tertib, tertata dan teratur dalam hubungan kerja yang berjenjang serta mempunyai prosedur kerja yang tersusun jelas dalam tatanan organisasi. Namun apa yang dirumuskan Weber tentang birokrasi, yang merupakan tipe ideal itu, sebenamya baru merupakan teori atau model suatu masyarakat modem yang telah melakukan rasionalisasi sikap dan tindakan-tindakannya. Dalam masyarakat tradisional, yang masih mendasari nilail-nilai feodal, prinsip tersebut belum dirasakan kebutuhannya. Baru ketika struktur dan persoalan-persoalan masyarakat menjadi semakin kompleks maka prinsip-prinsip itu terasa dibutuhkan.

Di negara-negara sedang berkembang, pemerintah umumnya membangun lembaganya lebih dahulu, tetapi pelaku pendukung sistem masih tradisional. Padahal prinsip yang dibangun oleh teori Weber (weberian), pelaku pendukung sistem harus dibudayakan lebih dahulu dalam pengaturan lembaga sehingga menjadi pola perilaku sehari-hari. Suatu lembaga/sistem dapat dikembangkan secara bertahap oleh perilaku yang memahami dan mampu melaksanakan prinsipprinsip birokrasi. Dengan kata lain, sebenamya materi prisip-prinsipnya dilakukan lebih dahulu sebelum formalisasi. Hal yang sering terjadi pula bahwa birokrasi yang sebenarnya sebagai sarana atau alat, justru dijadikan tujuan, maka diciptakanlah peraturan-praturan yang melebihi kebutuhan. Sehingga yang terjadi adalah formalitas didahulukan dan prosedur dipersulit.

\section{Dari uraian di atas} tampaknya antara upaya menciptakan kualitas SDM aparatur pemerintah akan sangat terkait dengan profesionalisme birokrasi, oleh karena itu dalam tulisan selanjutnya akan dibahas beberapa permasalahan yang berkaitan dengan upaya peningkatan kualitas aparatur peme- 
rintah dalam hubungannya dengan profesionalisme birokrasi.

\section{Perubahan ke arah Modernisasi Birokrasi}

Birokrasi yang ideal sebenarnya mengandalkan adanya pembiayaan yang mencukupi. Dalam perkembangan ekonomi sekarang, birokrasi menghendaki pengelolaan yang mendasarkan diri pada prinsippirnsip ekonomi. Birokrasi pertu memperhitungkan input-out put (masukan dan hasil) serta benefit and cost (manfaat dan biaya). Administrasi perlu dikelola sebagaimana perusahaaan, meskipun tidak dimaksudkan untuk mengejar keuntungan. Prinsip-prinsip birokrasi harus dipertimbangkan dengan rasionalitas ekonomi. Seperti apa yang dikemukakan oleh Gabler dan Osborne (1995) bahwa untuk lebih profesional maka perusahaan-perusahaan negara harus melakukan privatisasi. Dalam mencapai bentuk yang ideal, faktor penting yang menjadi perhatian adalah sumber daya manusianya (SDM).

Perubahan ciri birokrasi tradisional kearah birokrasi modern suatu kenyataan yang bersifat imperatif. Masyarakat yang dinamis telah berkembang dalam berbagai kegiatan yang semakin membutuhkan tenaga-tenaga profesional. Seiring dengan berbagai kemajuan yang diraih oleh masyarkat, kebutuhan akan pelayanan juga semakin kompleks serta menuntut adanya kualitas pelayanan.

Birokrasi dalam peranannya menghadapi tugas ganda, yakni di satu pihak birokrasi hanus mampu melakukan kiat-kiat strategis dalam rangka memberikan pelayanan yang lebih baik kepada masyarakat (outward looking), di lain pihak birokrasi juga harus mampu meningkatkan sumber daya manusia dalam lingkungannya (inward looking). Upaya perbaikan kualitas pelayanan idealnya akan diberikan, setelah sumberdaya manusianya dilatih dan mulai membudayakan apa yang menjadi tuntutan masyarakat. Oleh karena itu upaya peningkatan SDM secara profesional harus dilakukan secara simultan dengan upaya deregulasi debirokratisasi.

Deregulasi yang mungkin bisa dilakukan antara lain: 1) penataan peraturan perundangan. Secara prioritas harus dipilih peraturan mana yang perlu didahulukan untuk dibenahi, sehingga mampu menciptakan lingkungan yang kondusif untuk mengoptimalkan kinerja pegawai serta tidak menimbulkan masalah dalam masyarakat. 2) Birokrasi yang mengandung proses administrasi yang berbelit-belit harus disudahi, dengan menata ulang kewenangan antar instansi. 3) Mengoptimalkan bidang kepenawaian melalui pendidikan dan pelatihan. Bidang kepegawaian pendidikan \& pelatihan harus mampu membuat 
perencanaan aparatur baik dalam jumlahnya maupun kualitas dan kualifikasi yang dipertukan untuk jangka kedepan. Jumlah pegawai yang besar cenderung mengabaikan kegiztan kepegawaian, sehingga hasil pendidikan dan pelatihan sering belum menunjang atau terkait dengan karir pegawai, 4) Penerapan manajemen berbasis informasi (information management). Birokrasi tidak dapat terlepas dari kemajuan teknologi dibidang informasi. Tuntutan masyarakat terhadap kualitas pelayanan mengharuskan birokrasi untuk dekat dengan teknologi informasi. Kemajuan teknogi informasi mampu membuktikan tingkat efisiensi dan produktivitas suatu kantor. Pelayanan kepada masyarakat akan lebih ditingkatkan dan kemungkinan penyimpangan administrasi dapat dihindarkan apabila sistem pelayanan diolah dengan komputer.

Yang perlu mendapat perhatian adalah adanya beberapa hambatan yang mendasar untuk mencapai profesionalisme birokrasi antara lain: pertama adalah sifat elitis. Birokrasi belum sepenuhnya lepas dari kontrol politik. Dalam konteks demikian, dapat dipahami bahwa inisiatif maupun penggerak reformasi berasal dari atas. Karena dimotori dari atas, timbul kecenderungan bahwa fokus pembenahan lebih diarahkan pada jajaran administrasi maupun birokrasi tingkat atas dan mengabaikan birokrasi pada tingkat bawah. Kecenderungan ini misalnya nampak pada kesempatan pendidikan dan pelatihan, mereka yang berkesempatan biasanya pada lapisan menengah dan atas. Padahal, kualitas pelayanan justru sangat tergantung pada kemampuan dan kualitas petugas dilapisan bewah.

Hambatan kedua adalah politik. Hambatan politik menurut Magdalena (1998) adalah perbenturan kepentingan antara pemimpin politik dan pelaksana administrasi. Perbedaan prioritas dan parameter antara kepentingan politik dan administrasi sering menimbulkan konflik dalam pelaksanaan suatu program, akibatnya hasil akhir yang diperoleh menyimpang dari yang diharapkan. Perbenturan antara kepentingan administrasi dan politik misalnya tampak dalam rekrutmen, promosi maupun seleksi pelatihan bagi pegawai. Kriteria prestasi yang telah diterapkan di dalam sistem administrasi sering dikalahkan oleh faktor patron. Seseorang mendapatkan jabatan atau dipromosikan didasarkan pada hubungannya dengan patron politik tertentu dan bukan karena kemampuannya.

Pemikiran yang berkembang dari Agus Dwiyanto (1998) tentang upaya memperbaiki efisiensi nasional, pelayanan publik yang berteletele, tidak transparan dan menuntut biaya tinggi menuntut perubahan mendasar dalam sistem administrasi dan birokrasi. Altematif yang dita- 
warkan antara lain: 1) redefinisi misi birokrasi, 2) restrukturisasi birokrasi, 3) perbaikan mekanisme pengawasan.

Redefinisi misi birokrasi menekankan bahwa peran birokrasi yang selama ini sebagai pelayanan publik dan kegiatan pembangunan, mungkin sudah tidak tepat lagi dengan kondisi lingkungan birokrasi dan tantangan masa depan yang dihadapai oleh birokrasi, karena semakin menguatnya kemampuan swasta serta mekanisme pasar. Untuk itu peran tersebut bisa dikurangi dan diserahkan kepada sektor swasta. Birokrasi publik menekuni kembali misinya yang lain yang selama ini agak terabaikan, yaitu empowering dan enabling satuan-satuan sosial ekonomi masyarakat, sehingga mereka bisa menekuni kebutuhan mereka sendiri. Pemikiran diatas dilatari karena dominasi birokrasi dalam pelayanan publik dan kegiatan pembangunan seringkali justru menimbulkan berbagai patologi (penyakit) birokrasi, seperti: birokrasi tidak responsif terhadap dinamika dan perubahan dalam lingkungannya, mahal, lamban. Pengurangan dominasi birokrasi dalam penyelenggaraan pelayanan dan kegiatan pembangunan mendorong birokrasi berkompetisi dengan swasta untuk meningkatkan pelayanan publik. Upaya pengurangan tersebut harus memerlukan perubahan orientasi dan misi birokrasi publik. Misi birokrasi sebagai servlce providers diubah menjadi enabling dan empowering (peningkatan martabat kedudukan dan pemberdayaan masyarakat)

Restrukturisasi birokrasi perlu dilakukan dengan melalui desentralisasi, pengurangan sekat dan kotakkotak birokrasi. Dalam pemerintahan yang sentralis, biasanya orientasi pada juklak dan juknis (terutama di daerah) amat ketat karena harus sesuai dengan kepentingan dan keinginan pemerintah pusat. Kewenangan pejabat daerah untuk membuat diskresi dalam merespon berbagai kepentingan daerah sangat terbatas, akibatnya banyak program pembangunan yang kurang tanggap terhadap kebutuhan daerah. Adanya pengkotak-kotakan dalam birokrasi publik akan menimbulkan kesulitan melakukan koordinasi antar instansi.

Agar birokrasi mempunyai daya tanggap terhadap kebutuhan publik maka menuntut adanya restrukturisasi birokrasi. Hal tesrsebut bisa dengan desentralisasi kewenangan pengambilan keputusan kepada para pejabat birokrasi di daerah.

Perbaikan mekanisme pengawasan lebih ditekankan pada pengawasan oleh satuan-satuan sosial dan politik yang ada dalam masyarakat. Pengawasan juga ditujukan pada aspek-aspek daya tanggap dan pertanggungjawaban dari program dan kegiatan politik serta 
efisiensi. Selama ini pengawasan dari masyarakat dan lembaga sosial/politik menjadi tidak berdaya ketika mereka berhadapan dengan birokrasi publik. Untuk itu perbaikan efektivitaas pengawasan menjadi kebutuhan agar birokrasi menjadi tanggap dan mempunyai pertanggungjawaban yang semakin tinggi. Hal tersebut bisa dilakukan apabila ada keseimbangan kekuasaan antara masyarakat dan birokrasi publik, untuk itu perlu pemberian sumberdaya kekuasaan yang lebih kepada masyarakat/lembaga sehingga keinginan untuk mewujudkan birokrasi yang memiliki daya tanggap dan pertanggungjawaban dapat tercapai.

\section{Kualitas Aparatur Pemerintah}

Untuk memperoleh tatanan pemerintahan yang mendukung proses pembangunan suatu negara diperlukan SDM yang profesional. Masalah kualitas aparatur menjadi agenda dalam proșes peningkatan kualitas pelayanan publik. Peranan sumberdaya manusia dalam menjamin terciptanya birokrasi yang efisien sangat besar. Sayangnya masih banyak penyakit birokrasi yang bersumber pada persoalan sumber daya manusiz. Menurut Sondang $P$. Siagian (1994) penyakit birokrasi yeng ditimbulkan oleh perilaku manusia antara lain: penyalahgunaan jabatan/wewenang, pengaburan masalah, kecenderungan mempertahankan status quo, pilih kasih, ketakutan pada perubahan/inovasi dan risiko, takut mengambil keputusan, tidak mau bertindak., kurangnya komitmen, kurangnya koordinasi, kredibilitas yang rendah, kurangnya visi yang imajinatif, bekerja tidak produktif, ketidakmampuan menjabarkan kebijakan atasan, dll. Hal-hal di atas seharusnya mulai dikikis/dihilangkan apabila melekat pada setiap sosok aparatur pemerintah. Sikap dan perilaku aparatur seharusnya mengarah pada profesionalisme kerja, yang tidak temodai dengan penyakit-penyakit di atas.

Untuk menjadi birokrasi yang ideal harus ada keseimbangan antara tatanan birokrasi dan sumber daya manusia yang profesional. Seluruh langkah manajemen sumberdaya manusia harus diarahkan pada tersedianya tenaga kerja yang secara kualitatif dan kuantitatif memenuhi tuntutan keseluruhan tugas dan peranan birokrasi di mana mereka menjadi anggota.

Salah satu pendekatan yang telah dikembangkan oleh para ilmuwan administrasi negara dalam rangka peningkatan produktivitas aparatur pemerintah dan kualitas pelayanan, yang disebut Total Quality Management (TQM). Konsep TQM didasarkan tidak hanaya menekankan pada aspek hasil tetapi juga kualitas manusia dan kualitas prosesnya. Di samping itu, TQM mendorong partisipasi seluruh komponen organisasi dalam membina 
kerjasama untuk menghasilkan produk yang bermutu tinggi. TQM menggunakan pendekatan yang demokratis antara lain pemberian insentif kepada para anggota organisasi sehingga mereka meningkatkan tekadnya untuk memperbesar keberhasilan organisasi secara keseluruhan.

Pada awalnya konsep TQM diterapkan pada organisasi swasta, terutama dikalangan industri manufaktur dan jasa. Selama itu TQM terbukti ampuh dalam tiga hal, yaitu peningkatan mutu, produktivitas dan daya saing organisasai yang bersangkutan. Dewasa ini organisasi di lingkungan pemerintahanpun semakin sadar tentang peningkatan efisiensi, efektivitas, mutu dan produktivitas seluruh aparatur pemerintah. Oleh karena itu, berbagai pendekatan dan metode kerja diupayakan pula penerapannya di lingkungan birokrasi pemerintahan.

Beberapa prinsip TQM yang bisa diadopsi untuk pelaksanaan dalam organisasi publik antara lain: 1) fokus pelanggan, 2) obsesi terhadap kualitas, 3) pendekatan ilmiah dalam mendesain pekerjaan dan proses pengambilan keputusan, 4) komitmen jangka panjang dalam mengadakan budaya kerja, 5) kerjasama tim (tem work), kemitraaan, 6) perbaikan sistem secara berkesinambungan, 7) pendildikan dan pelatihan SDM sehingga dapat meningkatkan ketrampilan dan keahlilan profesionalnya untuk kepentingan peningkatan mutu organisasinya, 8) keterlibatan dan pemberdayaan pegawai dalam pengambilan keputusan dan pemecahan masalah, 9) kesatuan misivisi.

Upaya untuk menggerakkan pegawai dalam rangka meningkatkan kualitas/mutu kerja pegawai memang tidak mudah. Hambatan yang utama berhubungan dengan budaya organisasi, yang mempertahankan status quo sehingga menghambat kemajuan. Untuk itu yang penting adalah menciptakan organisasi pemerintah yang mampu menyesuaikan terhadap perubahan yang terjadi dan menggerakkan individu dalam organisasi yang membentuk budaya kerja Quality of Working Life, bahwa rilai kualitas selalu ditekankan dalam setiap kehidupan kerja organisasi. Peningkatan mutu sebenamya adalah upaya meningkatkan kinerja pegawai dengan penciptaan suatu perubahan yang tidak pernah tejadi sebelumnya, dengan melalui terobosan baru. Proses ini berlaku secara universal yaitu untuk setiap jenjang hierarkhi dari pimpinan sampai yang paling bawah. Oleh karena itu harus ada konsepsi yang sama tentang "mutu" bagi lembaga/bagian masing-masing. Komitmen mutu harus diformulasikan dalam setiap ruang kantor dan dalam setiap segi pelayanan. 


\section{Kesimpulan}

Dalam rangka membangun suatu bangsa peranan birokrasi lebih ditingkatkan. Peran ganda yang dimiliki oleh birokrasi disamping peningkatan kualitas pelayanan, juga menciptakan pemberdayaan dan meringkatkan martabat/kedudukan masyarakat. Disamping itu birokrasi harus peka temadap tuntutan dan perkembangan masyarakat. Disisi lain, keberadaan sumber daya manusia (aparatur pemerintah) harus dipersiapkan untuk menjalankan tugas pembangunan. Oleh karena itu budaya Quality Of Working Life dan pengendalian mutu dalam setiap aktivitas pemerintahan pertu diupayakan.

\section{Daftar Pustaka}

Amin Widjaja, 1993. Manajemen Mutu Terpadu. Jakarta: Rineka Cipta.

David Osbome \& Ted Gaebler, 1991. Mewiraswastakan Birokrasi (terjemahan). Jakarta: Teruna Grafica.

John Westerman \& Pauline Donoghue, 1992. Pengelolaan Sumber Daya Manusia (terjemahan). Jakarta: Radar Jaya Ofset.

Nicholas Henry, 1995. Administrasi Negara dan Masalah-Masalah Publik (terjemahan). Jakarta: Raja Grafindo Persada.
Soewamo Hardjosoedarmo, 1996. Dasar Dasar Total Quality Management, Yogyakarta: Andi Ofset.

Steven Cohen \& Ronald Brand, Total Quality Managemenet. San Francisco: Jossey-Bass Publishers.

Agus Dhama. 1985. Manajemen Prestasi Kerja. Jakarta: CV Rajawali.

\section{Biodata Penulis}

Dra. Rosidah, M.Si. adalah staf pengajar pada Program Studi Pendidikan Adminis-trasi Perkantoran Fakultas IImu Sosial Universitas Negeri Yogyakarta. 